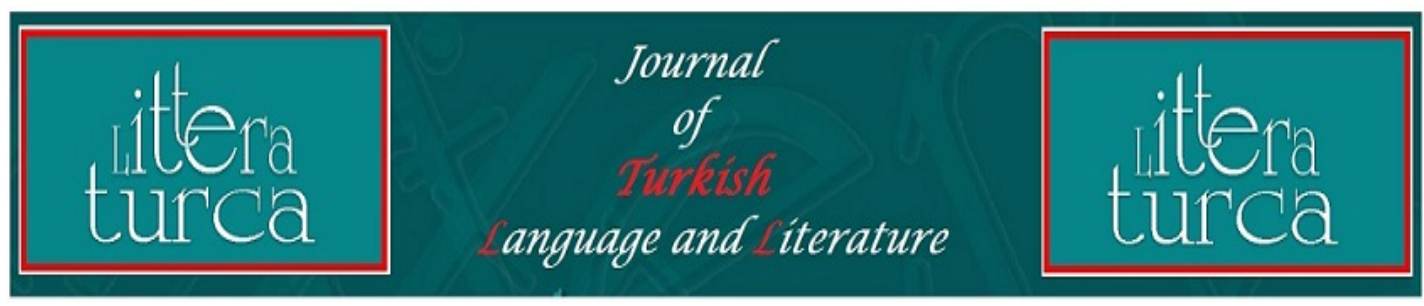

\title{
ANAMUR AĞZINDAN DERLEME SÖZLÜĞÜ'NE KATKILAR-2
}

\author{
Gönül ERDEM NAS*
}

\begin{abstract}
Özet
Anamur, Mersin ilinin kara yolu ulaşımı en zor ilçesidir. Yaklaşık dört bin yıllık tarihi geçmişe sahip olan ilçe, Osmanlı döneminden bu yana daima içcel ilinin kazasıdır. Bu uzaklık dil çalışması için çok bereketli bir saha sağlamaktadır. Deniz kenti olmasına karşın ekonominin neredeyse tamamının tarıma dayalı oluşu turizme bağı göçün önüne geçmiş böylelikle nüfusunun tamamı Yörük olan bu kentin yapısı da korunmuştur. Anamur, dil zenginliği bakımından akademik olarak çalışılmamış bir yöre olmasıyla birlikte yapılan yol çalışması ve hızla gelişen iletişim teknolojileri sebebiyle var olan bu zenginliğin ortaya hızlı bir şekilde çıkarılması gerekmektedir. Ilki yayımlanan bu çalışmada yer alan 3 köy şuan haritada yok olmuştur. Sebebi ise Kıbrıs'a gidecek suyun Anamur'dan sağlanması böylelikle baraj suları altında kalmasıdır. Bu çalışmada birinci çalışmada gidilen köylerle birlikte hiç gidilmemiş diğer köylere gidilerek derlemeler yapılmış bunlar kayıt altına alınarak transkribe edilmiştir. Derlemede 57 kelime ve kelime öbeği tespit edilmiştir. Bu kelime ve kelime öbeklerinin 41 tanesinin Türkiye Türkçesi Ağızları Sözlüğü (Derleme Sözlüğü)'nde bulunmadığı geri kalan 16 kelime ve kelime öbeğinin ise sözlükte farklı anlamlarda bulunduğu görülmüştür. Bu anlamda çalışmanın Derleme Sözlüğü’ne katkı sağlaması ve bu Yörük coğrafyasının keşfedilmeyi bekleyen birçok yeri için araştırmacılara ilham-kaynak sağlaması amaçlamaktadır.
\end{abstract}

Anahtar Kavramlar: Yörükler, Anamur Ağzı, Derleme, Dilbilim.

\section{CONTRIBUTION TO SUPPLEMENT DICTIONARY FROM ANAMUR DIALECT-2}

\begin{abstract}
Anamur, is the province where transportation is the most difficult to one to Mersin distric. Its historical past go es back to 4 thousand years and since the period of Ottoman Empire became a province of içel. The far distance of Anamur makes language studies quite valuable and fruitfull. Even it is on the shore of the Medditerranian sea the economy is based on aggricultural production and this feature prevented the migration to the province. Thus almost all settlers live here are Yörüks. Anamur, is one of the fields which have not been studied academically in point of linguistic richness. Due to technological development in mass media and especially road construction between Mersin and Antalya cities are effecting the traditional life and linguistic structure of people live around Anamur. For these reasons the lingusitic richness of the region must be academically studied and preserved for Turkish literature. The study consists of two valumes. The first had been published before and 3 villages which were contained in the sample group of the first study now are dissapeared on the map because the dam which is being built to supply drinkable water for Cyprus is into Anamur borders. So such 3 villages remained under the water of the dam. Considering this situations in addition to villages visited in first study some other villages had been added to sample group. Via the study, supplementation were done and speeches of narrators were recorded to be transcribed by researcher. After the result of supplenementation 57 words and word phrases were identified. It was determined that 41 of such words and phrases were not found and the rest 16 have different meanings in Türkiye Türkçesi Ağıları Sözlüğü (Supplement Dictionary of Turkish of Turkey). In this sense it is expected from the study to encourage researchers to discover the richness of the geoghraphy where Yörüks live and to make a contribution to Supplement Dictionary as well.
\end{abstract}

Keywords: Yörüks, Anamur Dialect, Supplementation, Lingusitic.

* Okt. Dr., Mersin Üniversitesi, gonulerdem2002@yahoo.com

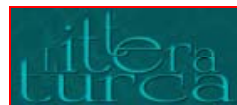

Journal of Turkish Language and Literature

Volume:1, Issue: 1, Summer 2015, (1-8) 


\section{Giriş}

Anamur adının Helen dilinde "Rüzgar" anlamına gelen ANEMOS sözcüğünden türediği ve Antik kentin de adı olan Anemurium'un “Rüzgarlı Burun” adını buradan aldığı tahmin edilmektedir. Bu görüş yaygın olsa da buna karşı çıkanlar da bulunmaktadır. Helen dilinde Anemourion sözcüğünün yer almadığı bu sözcüğe yakın anlamın ise "Fırıldak" anlamına geldiği, bundan dolayı sözcüğün bir yer adı olmayacağı ileri sürülmektedir. Kelimenin kökeninin Lluwi dilinden "Yüce Ma" anlamı taşıdığı ve Anadolu'da da bu adla anılan pek çok kent olduğunu savunan başka bir görüş de vardır (Umar, 1993:72).

Anamur, İçel ilinin büyük oymaklarından biri olan Yıva oymağına mensup bir kazadır. Yıva oymağının Küçük Yıva ve Büyük Yıva kolları 14 yerleşim bölgesi halinde bu coğrafyaya yayılmıştır (Sümer, 1992: 180).

Osmanlı dönemindeki kayıtlara göre Anamur'da ağırlıklı olarak Karaketili, İshaklı, Tekeli, Bahşiş, Tahtacı ve Sarıkeçililer Aşiretlerinin yaşadığı bunların yanı sıra Ermeni ve Rumların az da olsa Yunan uyrukluların, Kıpti, Girit ve Dobruca Muhacirlerinin de olduğu yer almaktadır (Erim, 2014: 105).

Antalya, Silifke, Mut, Osmaniye-Adana gibi Anamur yöresine yakın yerlerin ağız özellikleri çalışılmış olmasına rağmen, yöre ile ilgili çalışmaların çok az olduğu görülmektedir. Anamur ağzı, Batı Grubu Ağızları içerisinde Tarsus'u da içine alan VII. grup ile birlikte genel ses, şekil özellikleri itibariyle Anamur ağzı IX. alt grupta da yer almaktadır (Karahan, 1996:11).

Birinci çalışmada Anamur yöresinin merkezi ile birlikte daha çok doğusunda yer alan köylere ve yerleşim yerlerine gidilerek derleme yapılmıştır. Bu çalışmada ise batısındaki yerleşim yerlerine gidilerek derleme yapılmıştır. Derlemeler sonucunda bu iki çalışmada farklılıklar bulunmaktadır. Doğuda yer alan köy ve yerleşim yerleri sahile daha yakın olduğu için iklim şartlarının etkisiyle yaylaya göç devam etmektedir. Batıda yer alanlar ise denizden uzak olduğundan yayla göçüne çok rastlanmaktadır. Bu durum ağız özelliklerine de yansımıştır. Doğuda yer alan yerleşim yerlerinde göçebe hayatı ile ilişkili kelimeler; kilim, deve, yolculuk gibi kavramlar kullanılırken, batıda yer alanlarda ise yerleşik hayata dair özellikle yemek adlandırmaları sıkça kullanılmaktadır. Bu farklıık göçe dayalı yaşam biçimi ile beraber Anamur'un merkezi yönetiminin uzun yıllar boyunca Anamur'un batısında yer alan Nasreddin ve Ortaköy gibi yerleşim yerlerinde bulunmasından kaynaklanmaktadır. Böylece buralarda yaşayan halk yerleşik hayata Anamur'un doğusunda yaşayanlara göre daha erken geçmiştir. Göçe dayalı oluşamayan yemek kültürü ve yemek adlandırmaları bundan ötürü Anamur'un batısındaki ağızda daha yaygın kullanılmaktadır.

Derlemeler Anamur şehir merkezine bağlı köylerle birlikte Bozyazı ilçesi ve Tekmen-Tekeli beldelerini de kapsamıştır. Toplanan malzeme titizlikle incelendikten sonra transkribe edilerek Derleme Sözlüğü’nde bulunmayan ve Derleme Sözlüğü’nde olduğu hâlde farklı anlamları tespit edilen kelimeler olmak üzere ikiye ayrılmıştır. Yine bu kelime ve kelime öbekleri alt başlıklar ve örneklerle işlenmiştir.

\section{DERLEME SÖZLÜĞÜ’NDE BULUNMAYAN KELIMELER}

\section{A. ADLAR}

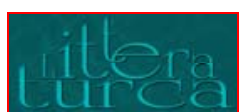

Journal of Turkish Language and Literature

Volume:1, Issue: 1, Summer 2015, (1-8) 
Börtleme: Sebze, hububat ve baklagilin çok az haşlanmasıyla oluşan yiyecek.

Börtleme deriz bilir miñ? (Tenzile)

Deli keş: Keş, yörede çökeleğe verilen ad olmakla birlikte deli keş ise çökeleğin yapım aşamasında sütün kesilmeyerek sulanmasıyla oluşan katıya yakın çökelek ve lor benzeri yiyecek.

Süt kesilmez olur oña deriz deli keş deyi (Tenzile)

Düşḡar: Şakacı, nüktedan kimse.

Şonun da hẻç düşḡarlığı geçmez. (Ortaköy)

Dökmecik: Lokma tatlısı.

Datlı ne ederiZ işTe dókmecik yaparız. (Tenzile)

Ekmek pişesi: Yufka ekmeğin ufalanıp üstüne biberli su dökülerek yapılan yemek.

Ekmék pişesiñi de yaylıda çoh yaparız. (Tenzile)

Fıyyık: Dilin dişler arasına sıkıştırılmasıyla çıkarılan ıslık sesi.

Arabâya fıyyık çalıver (Ortaköy).

Fıstık góllemesi/góllesi: Sadece yöreye özgü kabuklu taze yer fıstığının tıpkı mısır gibi haşlanarak yapılan bir tür atıştırmalık yiyecek.

Fıstığın góllemesi burlarda çok olur (Tenzile)

Filloz: Kerevizgillerden bir kök bitki olan gölevezin küçük ve körpe olanından yapılan yemek ve bitkinin adı.

Góleveze göre filloz dahaçabuk pişiverir (Tenzile)

Füyyük: Dudakları büzüştürerek çalınan ıslık.

Füyyük çala çala gèder. (Ortaköy)

Galiptoz: Okaliptüs ağacı.

Galiptoz dellèrdi endē āca. (Nasreddin)

Gólevez: Kerevizgillerden kök bir sebze.

Góleveze göre filloz dahaçabuk pişiverir (Tenzile)

Gölleme/gólleme: Herhangi bir sebzenin haşlaması.

Haşlamaya da gólleme deriz. (Tenzile)

Hırthırt: Patates kızartması.

Patatesi hayvan yağında hırthırt ederiz. (Tenzile)

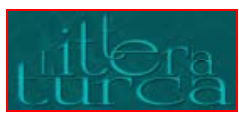


ilēen/ileğen çöreği: Un, karbonat, yer fıstığı ve yumurtayla yapılan bir tür çörek.

ilēn çórēni bayramlarda yaparız (Tenzile).

İzve: Ambar, yüklük.

Yatak ocak hep izvede. (Melleç)

Kakırt/Kıkırt: Hayvanların iç yağından yapılan bir tür meze.

Kakırt ġışın eyi olur (Melleç)

Malutra: Dereotuna benzer kırçılı bir bitkiden yapılan pilav.

Malutra da bir ot heye dereotu gibi selemle gibi ama şekli farklıolur (Tenzile)

Mollaç: Bayat darı (mısır) ekmeğinin ufalanıp üstüne yağlı soğan salça sosunun dökülmesiyle oluşan yemek.

Eskiden abıla yemēmiş mollaç (Ören)

Palize: Nişasta ve pekmezin karıştırılmasıyla oluşan bir tür tatlı.

Palize ġoláy olur (Melleç)

Selleme: Dere kenarında ve sulak yerlerde yetişen semizotuna benzer bir ottan yapılan yemek ve böreğe verilen ad.

Malutra da bir ot heye dereotu gibi selemle gibi ama şekli farklıolur (Tenzile)

Sızzıḳ: Hayvan yağının küp küp doğranıp ateşte renk alana kadar pişirilmesiyle oluşan yemek.

Sızzık eskiden hayvan bol ıkan çoh olurdu. (Tenzile)

Zıllıngaç/Zıllıncaḳ: Salıncak.

Annem bā zıllıncaḳ gurar ıdı. (Tenzile)

\section{B. FiiLLER}

Çatdaş ol-: Sataşmak, musallat olmak.

Milletle iyi geçin kimseyle çatdaş olma! (Ortaköy)

Gamçala-: Bir şeyi avuçlayarak almak.

Bayram şekerlerini de çocuḳlar gamçaladı (Dereköy)

Ġañsır-: Balgam çıkarmak.

Hasta çok ġañsırıverir. (Tenzile)

Gımcın-: İsteksiz, iştahsız.

Gımcınıp durma yemēni hoş ye! (Ortaköy)



Journal of Turkish Language and Literature

Volume:1, Issue: 1, Summer 2015, (1-8) 
Hörüle-: Ergen olmak.

Heye oñun ġızı da hörülemiş (Tekeli)

Tünglü-: Zıplamak.

Yollar bozuk oldūñdan kēri araba tüngülediydi. (Tekmen)

Zırpaş-: Birisini terleyerek ya da sinirlenerek saldırması, karşıdaki kişiyi sarsması.

Onu dèyivèrince çocuk zırpaşıverrdi. (Orhana)

Zırpaş-: Abanmak, sırnaşmak.

Sıcāñı üstüme sıvama zırpaşıp durma! (Dereköy)

Zıvarı ver-: Saygısızca konuşup karşılık vermek.

Ben ona düzgün otur dedim o zıvarıverdi (Dereköy)

\section{IKILEME}

Gabalbazar: Göz kararı, ölçüp tartmadan tahmini değer biçme.

Ġüçǚk haşanın üstüñde patatesi gabalbazar verdim. (Ortaköy)

D. ÜNLEM

Bāz: Şaşırma ünlemi

O ne bāz! (Ortaköy)

Nagtan: Ne yapıyorsun?

Hoyn nagtan? (Kalınören)

Nindeñ: Ne yapacaksın?

Nindeñ endē ekmē evde var Zaten (Dereköy)

\section{E. ZARF}

Adı belli: Oldu olacak bir durum için kullanılan sözcük öbeği

Adı belli endē donu da çıkarıver. (Ortaköy)

\section{F. DEYIMLER}

Çit dedĩ geççi oñmaz: Bunun söylediği sözden hayır gelmez

Dayak çocūn sırtında çığrınıyor: Çok yaramaz çocuklar için dayak istiyor anlamında kullanılan bir deyim.

Goyaḳ goyaḳ obañ olsun: Sevilen birine çoğalsın türesin anlamında kullanılan bir deyim.

Góñü goknasıca: Ölüsü koksun anlamında bir beddua.

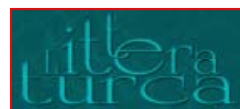

Journal of Turkish Language and Literature

Volume:1, Issue: 1, Summer 2015, (1-8) 
A góñü ġoḱasıca niñden? (Tekmen)

Yōl yōImāsıca: Yok olmayasıca anlamında bir deyim

Yōl yōlmāsıca gene güldürdü milleti. (Sarıdana)

\section{DERLEME SÖZLÜĞÜ’NDE OLDUĞU HÂLDE FARKLI ANLAMLARI TESPIT EDILEN KELIMELER}

\section{A. ADLAR}

Çileme (Krş. DS III/ İki yaşında olan keçi, hafif ve ince yağan yağmur, çisinti, ıspanak, pancar gibi sebzelerle pirinç ve bulgur karıştırılarak yapılan bir çeşit yemek): Turp otunun kavrulup üstüne susam dökülerek yapılan bir tür yemek.

Burda otTan da yemek pişiririz çileme, dağarcık bunnar da var (Tenzile)

Dağarcık (Krş. DS IV/ Saksı, insandan yumak şeklinde dökülen solucanlar, yüzülmüş hayvan derisi, çocukların altlarına konulan lâstik, muşamba, dağlarda yetişen yabanî bir yemiş): Kılçıklı fasulye ve bu fasulyeden yapılan zeytinyağlı yemek.

Burda otTan da yemek pişiririz çileme, dağarcık bunnar da var (Tenzile)

Gadaḳ (Krş. DS VI/XII/ Çivi, kadar, kazan kulpunun tutturulduğu yer, tırpanın ökçesinin sağlam olması için tırpana vurulan demir): Küçük çocuklar için kullanılan ufaklık anlamındaki söz.

Gel gadak yanıma otur.

Ġatmer (Krş. DS VI/ XII/ Tandır ve saç .üzerinde pişirilen yağlı ekmek, katmer, yağlı sac ekmeği, katmer): Hayvan iç yağının küçük küçük doğranıp yufka içine konulması ve bu işlemin dört kez yapılmasıyla oluşan böreğin sacda pişmiş haline verilen ad.

Ne edecēz ġatmer deriz onu yaparız, ġıvrışık pişiririz, góce deler onu ederiz yalañız o datı. (Tenzile)

Ġıvrışık/ḳıvrışık (Krş. DS VIII/ XII/ Pancar yaprağı, kıvırcık): Kılçıklı taze fasulye ve bununla yapılan zeytinyağlı yemeğe verilen ad.

Ne edecēz ġatmer deriz onu yaparız, ġıvrışık pişiririz, góce deler onu ederiz yalañız o datlı. (Tenzile)

Góce (Krş. DS VI/ Tavşan yavrusu): Pekmez ve unla yapılan bir tür helva.

Ne edecēz ġatmer deriz onu yaparız, ġıvrışık pişiririz, góce deler onu ederiz yalañız o datı. (Tenzile)

Kaḳaç (Krş. DS VIII/ XII/ Pastırma, kavurma, ağaçkakan, soğuktan donmuş ıslak bez, zayıf, kekeme): Kurutulmuş meyve, özellikle kuru incir.

Yaz oldu muydu kaḳaç ederdik. (Ortaköy)

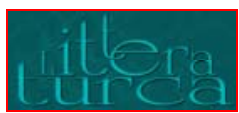

Journal of Turkish Language and Literature

Volume:1, Issue: 1, Summer 2015, (1-8) 
Kömbe (Krş. DS VIII/ XII/ İki saç arasında ya da külde pişirilen mayasız ekmek, kızgın küle gömülerek pişirilen bir çeşit kalın ekmek, geniş yüzlü dolgun vücutlu kimse): Yörede dügülcük denilen ince bulgurun salça, nohut ve baharattan oluşan harçla karıştırılarak elde köfte şekli verilip kömür ateşinde pişmesiyle oluşan yemek.

Ahşama papara pişiririñ, kómbe ederiñ. (Çarıklar)

Kóşe (Krş. DS VIII/ Yapılarda köşelere konan iri taş, köşe): Birisine veya bir şeye zarar vermek için seçilen sivri kenarlı büyükçe taş

Kópē kóşēbi saldım ġaçTı getTi.(Kızılaller)

Papara (Krş. DS IX/XII/ Pulluğa benzer, ağaçtan yapılmış bir tarım aracı, top, belirtilen çukura düşürülerek oynanan bir çeşit oyun): Mısır ekmeğinin ufak ufak doğranıp üstüne salça ve bol soğandan yapılan sosun dökülerek yapıldığı yemek.

Ahşama papara pişiririñ, kómbe ederiñ. (Çarıklar)

Yamaç (Krş DS XI/ Yan, yakın, karşı, bedel): Bir şeyin veya bir kimsenin eşi, teki.

Bu telliğĩn yamacı nerde? (Tekeli)

Bu ġadın yamacını bulmuş (Dereköy).

\section{B. FiíLLER}

AvıkTır- (Krş. DS I/ Alıştırmak, cesaretlendirmek): Özellikle av köpeklerini ava alıştırmak.

Kópē getiriver de avıkTıralım. (Melleç)

Çalkan-( Krş. DS III/ XII/ Üzülmek, darılmak): Sere serpe uzanmak.

ġızım çalkanma doğru otur. (Dereköy)

Çıngış- (Krş. DS III/ Uyuşmak, ürpermek): Vücudun bir yerindeki ağrının ara ara tekrarlaması, zonklamak.

Dişimdēki çürük çıngışıverdi.(Bozdoğan)

Gaysaḳlan- (Krş. DS VI/ Sıvılar kabuk, zar bağlamak, mantarlanmak): Çok fazla kirlenmek, kir bağlamak.

Yīkanmaya yīkanmaya atleTi gaysaḳlañmış (Ortaköy).

\section{SONUÇ}

Anamur ilçesi, ağız çalışmaları bakımından oldukça korunmuş bir yöredir. Çalışma Anamur ilçe merkezi ile birlikte 9 yerleşim birimini kapsamaktadır. Derleme 57 kelimeden oluşmaktadır. Bunların 41 kelimesi, Derleme Sözlüğü’nde bulunmamakta, 16 tanesi ise farklı anlamlara gelecek şekilde yer almaktadır. Çalışma yapılan yerlerden elde edilen verilerin incelenmesi sonucunda 13 fiil, 32 ad, 1 ikileme, 3 ünlem, 1 zarf ve 5 deyim tespit edilmiştir. Kayıt altına alınıp transkribe edilen bu kelimeler, Derleme Sözlüğü'ne katkıda bulunması ve bu alanda çalışmak isteyenlere yol gösterici olması bakımından önemlidir.



Journal of Turkish Language and Literature

Volume:1, Issue: 1, Summer 2015, (1-8) 


\section{KAYNAKÇA}

Akar, Ali. (2004). Muğla Ağızları, Muğla Üniversitesi Yayınları: 50, Muğla.

Büyük Türkçe Sözlük (http://tdkterim.gov.tr/bts/).

Ercilasun, B. Ahmet. (1983). Kars ili Ağızları, TDK, Ankara.

Erdem, Mehmet Dursun, Bölük Ramazan. (2011). Antalya ve Yöresi Ağızları (Giriş- İnceleme-Metinler), Turkish Studies Yayınları, Ankara.

Erim, Mustafa. (2014).Osmanlı Belgelerinde İçel Sancağı Anamur Kazası, Hemen Kitap, Mersin.

Gülensoy, Tuncer. (1988). Kütahya ve Yöresi Ağızları, TDK Yayınları, Ankara.

Karahan, Leyla. (1996). Anadolu Ağızlarının Sınıflandırılması, TDK Yayınları, Ankara.

Korkmaz, Zeynep. (1994). Güneybatı Anadolu Ağızları, TDK Yayınları, Ankara.

Öztürk, Erol. (2009). Silifke ve Mut'taki Sarıkeçili ve Bahşiş Yörükleri Ağzı, TDK Yayınları, Ankara.

Sümer, Faruk. (1992).Oğuzlar, TÜDAV, İstanbul.

Türkiye Türkçesi Ağızları Sözlüğü (http://tdkterim.gov.tr/ttas/)

Umar, Bilge. (1993).Türkiye'deki tarihsel Adlar, İnkılâp Yayınları, İstanbul.

Yalman, Ali Rıza. (1977). Cenupta Türkmen Oymakları, Kültür Bakanlığı, Ankara.

Yıldırım, Faruk. (2006). Adana ve Osmaniye İlleri Ağızları I-II, TDK Yayınları, Ankara.

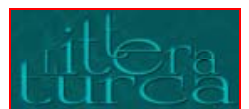

